\title{
Early development of dietary patterns: transitions in the contribution of food groups to total energy-Feeding Infants and Toddlers Study, 2008
}

Kathleen C. Reidy ${ }^{1 *}$, Denise M. Deming ${ }^{1}$, Ronette R. Briefel ${ }^{2}$, Mary Kay Fox ${ }^{3}$, Jose M. Saavedra ${ }^{4}$ and Alison L. Eldridge ${ }^{5}$

\begin{abstract}
Background: Early dietary patterns are critical to growth and development and play an important role in development of food preferences and habits. The objective of this paper is to describe when different foods enter the diet and how food consumption changes over the period of complementary feeding.

Methods: We analyzed cross-sectional 24-h dietary recall data from the Feeding Infants and Toddlers Study (FITS) 2008, a nationally representative sample of young children. Data are presented for 7 age groups: 6-8.9 months $(n=249)$, 9-11. 9 months $(n=256), 12-14.9$ months $(n=243), 15-17.9$ months $(n=251), 18-20.9$ months $(n=219), 21-23$. 9 months $(n=212)$ and $24-47.9$ months $(n=1461)$. Per capita energy was calculated from major food groups and specific types of food within each food group.

Results: The predominant source of energy in the infant diet was milk (breast milk and infant formula), contributing $98 \%$ of energy at 0-3 months, and $91 \%$ at 4-5 months. At 6-8 months, when complementary feeding had begun for most infants, $69 \%$ of daily energy was coming from milk, $11 \%$ from grains, $6 \%$ from fruits, $5 \%$ from vegetables and $4 \%$ from mixed dishes. The diet then quickly transitioned until at 21-23.9 months, $26 \%$ of energy came from milk, with other key sources of energy being grains (17\%), mixed dishes (14\%), meats (12\%) and sweets (12\%). The period from 4 to 14 months was the most dynamic period of change regarding the introduction of complementary foods for all food groups, with a slower rate of change between 15 and 24 months. After 24 months, the diet stabilized and included less energy from milk (20\%) and vegetables (4\%) and more energy from mixed dishes (18\%), grains (16\%), and sweets (17\%), and began to resemble adult diets.

Conclusions: Feeding in the first 24 months shapes dietary patterns, and thus provides a critical window of opportunity to shape subsequent dietary patterns and eating habits. Findings from FITS identified high sweet and low vegetable consumption as key issues. Education is needed for health care professionals and parents on feeding during this important period. These findings can be used to support the development of specific and actionable feeding guidance for parents.
\end{abstract}

Keywords: Complementary feeding, Dietary intake, Food groups, Infant, Toddler, Child eating, Feeding guidance

\footnotetext{
* Correspondence: Kathleen.Reidy@rd.nestle.com

${ }^{1}$ Nestle Infant Nutrition, Global R and D, 12 Vreeland Road, Florham Park, NJ 07932, USA

Full list of author information is available at the end of the article
}

(c) The Author(s). 2017 Open Access This article is distributed under the terms of the Creative Commons Attribution 4.0 International License (http://creativecommons.org/licenses/by/4.0/), which permits unrestricted use, distribution, and reproduction in any medium, provided you give appropriate credit to the original author(s) and the source, provide a link to the Creative Commons license, and indicate if changes were made. The Creative Commons Public Domain Dedication waiver (http://creativecommons.org/publicdomain/zero/1.0/) applies to the data made available in this article, unless otherwise stated. 


\section{Background}

Early dietary patterns are critical to growth and development in children and play an important role in the development of food preferences and habits [1,2]. The selection of foods offered, repeated exposure to new foods, as well as the feeding style parents use are all critical elements in the development of healthy eating habits in infants and toddlers [1-4]. Improper infant feeding practices have been implicated in early development of overweight in infants, and infant overweight is a strong predictor of early childhood obesity [5-8]. Early dietary habits are also associated with food preferences later in childhood [9-11]. This is true for fruits and vegetables [9-11] and also for less-healthy dietary components such as sugar-sweetened beverages and other sources of discretionary calories $[10,12]$.

The Feeding Infants and Toddlers Study (FITS) in the United States (US) has been a source of information on the dietary changes as children move from an all-milk diet to foods of the family table [13-19]. Previous results have shown that some children begin consuming sweets very early in life and that percent consuming steadily increases during the first 2 years of life [18]. Even as early as $4-5$ months, almost $5 \%$ of infants were being fed sweets and by $2-3$ years, $80 \%$ consumed some type of sweets or sweetened beverage on any given day $[16,18]$. About $30 \%$ of all infants and children up to age 4 did not receive any discrete servings of vegetables during an average day, and by 2 years, more children consumed sweets than either fruit or vegetables [16]. Data from both FITS 2002 and the National Health and Nutrition Examination Survey (NHANES) 2005-2012 have shown that leading sources of energy in the diets of young children include $100 \%$ juice, grain based mixed dishes, fruits, sweet bakery products, breads, rolls and tortillas, poultry and sugar-sweetened beverages $[15,20]$.

This objective of this paper is to describe when different foods enter the diet of infants and young children and how food consumption changes over the period of complementary food introduction up to the age 4 years. This research builds upon earlier FITS research and develops a comprehensive picture of the transitions in the infant and toddler diet with respect to sources of energy, by assessing very narrow age groups across major food groups and a large number of more specific food types. It describes which food groups and specific food types become more or less important sources of energy at various stages during the transition from an all milk diet into meals from the family table. It also explores what foods are contributing to the increase in calories as growing children consume more daily energy.

Early feeding has been shown to be critical for both immediate growth and development as well as long term impact on overall health, development of food preferences and establishment of dietary habits. Several issues of concern, previously identified in the diets of children at an early age, such as high sweet consumption and low fruit and vegetable consumption, merit a more detailed understanding of when and how these issues develop. This information can provide valuable insights to those who are developing dietary guidance for children birth to 24 months as well as those on the front lines counseling parents on how to feed young children.

\section{Methods}

FITS 2008 is a cross-sectional survey of a national random sample of US children from birth through age 47 months [21] and is similar in design to the FITS 2002 [22]. Subjects were recruited from targeted-list frames within the New Parents Database and the Consumer Database from Experian Inc. (Costa Mesa, CA), a commercial vendor. The sampling frame included children from birth to 47 months from all US states and the District of Columbia [21]. All instruments and procedures are available on-line [23] and were reviewed and approved by Mathematica Policy Research's independent institutional review board at the time of the study (Public/ Private Ventures, Philadelphia, PA).

Among sampled households that could be reached to verify an age-eligible child, $60 \%$ responded to the recruitment interview. Among respondents who completed the recruitment interview, $78 \%$ completed a $24-\mathrm{h}$ dietary recall. The overall analytic response rate among those located with an eligible child was $47 \%(0.60 \times 0.78=0.47)$, similar to the rates achieved in other large-scale telephone surveys at the time [21]. Data were weighed to account for nonresponse and under-coverage of some subgroups of children not included in the sample frame and to reflect the US population.

\section{Data collection methods and outcome measures}

Study participants received up to three telephone interviews between June 2008 and January 2009. The first was a recruitment interview to determine whether there was an age-eligible child and to collect household and child demographics, child feeding history (for example, whether the child was ever breastfed and when solid foods were introduced), and information about the child's physical activity and sedentary behaviors. The second call was a dietary interview, including a 24-h dietary recall and questions on breastfeeding, and the introduction of foods. For a subset of the sample, a second 24-h dietary recall was collected 3 to 10 days following the first and was used to estimate usual nutrient intake distributions. Before the dietary interview, respondents (the primary caretaker of the selected child, typically the mother) received a packet of materials via mail, including a study letter, food model booklet, ruler, liquid measuring cup with instructions, and instructions for 
recording foods consumed while the child was in child care [21].

Dietary interviews were conducted by telephone and administered by certified dietary interviewers at the University of Minnesota's Nutrition Coordinating Center using the FITS 2008 protocol and the Nutrition Data System for Research (NDSR) (version 2008, University of Minnesota Nutrition Data System for Research, Minneapolis). All respondents received a $\$ 20$ incentive for participation in the first 24-h dietary recall and an additional $\$ 10$ for the second 24-h dietary recall. Approximately $26 \%$ of the dietary recalls were collected for weekend intakes (i.e., Saturday or Sunday) and 74\% reflected intake on weekdays (i.e., Monday through Friday) [21].

\section{Food groups}

The NDSR 2008 included more than 18,000 foods with values for 156 nutrients, nutrient ratios, and other food components. The database contained more than 7000 brand-name products, including many baby/toddler foods and infant formulas. A total of 358 foods were added to the FITS 2008 database to reflect foods commonly consumed by US infants and toddlers at the time. When a reported food was not available in the database, the item was entered as "missing" along with details (brand name, description, preparation details, package size, dimensions, and weight or number consumed) and resolved after data entry was completed for the recall [21].

All foods and beverages reported in the 24-h dietary recalls were assigned to food groups in a manner consistent with those used for the food group analysis in the 2002 FITS [14]. The 2002 food groups were updated and expanded, as needed, to incorporate new foods and beverages reported in the FITS 2008 and to address the research objectives on consumption of foods and food groups/subgroups. Estimates were based on foods as consumed. That is, food mixtures, such as soups, pizza, or pasta-based dishes, were considered single items and were not broken down into their constituent ingredients. In this manner the estimates for the energy from lower energy density foods such as vegetables and fruits should be considered as lower-bound estimates because they can also be consumed as part of other mixtures in the diet.

Food group consumption data was used to calculate the per capita energy consumption from different foods and food groups. This was done by adding all of the calories from a specific food or food group within a given age group and then dividing by the number of children in that specific age group. Percentages were then calculated by dividing the per capita calories from a specific food or food group by the total number of calories consumed by the children in that age group multiplied by 100. Percent of energy from major food groups was estimated for children $0-47$ months $(n=3273)$ in 12 age groups: $0-3.9$ months $(n=216), 4-5.9$ months $(n=166)$, 6-8.9 months $(n=249), 9-11.9$ months $(n=256), 12-$ 14.9 months $(n=243), 15-17.9$ months $(n=251), 18$ 20.9 months $(n=219), 21-23.9$ months $(n=212), 24-29.9$ $(n=365),(30-35.9 \quad(n=371), 36-41.9(n=395)$ and $42-$ $47.9(n=330)$. Given the very small changes in dietary patterns seen from 0 to 5.9 months and after 24 months, we have focused primarily on infants and toddlers 6-23 months and displayed the toddlers from 24 to 47 months $(n=1461)$ as a single age group.

\section{Statistical analysis}

Descriptive analyses were based on children with complete 24-h recalls on day 1 . Sample weights were calculated to account for nonresponse and to weight the sample to reflect the US population for the appropriate ages and survey year. Calories from various food groups were estimated using the Statistical Analysis System (SAS Version 9.1.3, 2004, SAS Institute, Cary, NC) and accounted for the weighting and design effects. No statistical tests were performed, as the purpose of this analysis is to describe transitions and how the diet evolves over time as the child grows and consumes a greater amount of energy. A 1-day estimate from 24-h recalls for the purpose of estimating mean group intake has been previously shown to be appropriate [24]. All reported foods and beverages were included in the estimates, regardless of the amount consumed.

\section{Results}

Early in life, the predominant source of energy in the infant diet was milk (breast milk and/or infant formula), contributing $98 \%$ of energy at $0-3$ months, and $91 \%$ at 4-5 months (Fig. 1, Table 1). A small amount of other foods were introduced to more than half of infants at 45 months, with $5 \%$ of daily energy from grains and very little from any other food group.

By 6 months all food groups have entered into the diet. The speed of incremental contribution of all food groups to total daily energy is dramatic in the 10 month period between 4 and 14 months, going from 10 to $65 \%$ of total daily energy, and then slows down and increases to $80 \%$ over the next 10 months. After this period, the relative individual food group contribution to energy intake remains remarkably stable, despite significant changes in the variety of foods consumed as the child grows.

At 6-8 months, when complementary feeding has begun for nearly all infants, $69 \%$ of daily energy was coming from milk, with grains becoming a key source of energy (11\%) as well as fruits (6\%), vegetables (5\%) and mixed dishes (4\%). The diet then quickly transitioned until at 21-23.9 months, $26 \%$ of energy came from milk, with other key sources of energy being grains (17\%), mixed dishes (14\%), meats (12\%) and sweets and snacks 
(12\%). After 24 months, the diet stabilized and included less energy from milk (20\% daily energy) and more energy from mixed dishes (18\%), grains (16\%), and sweets and snacks (17\%). At the age of 24-47 months, energy from vegetables was at approximately $4 \%$ of daily energy, less than that seen during the complementary feeding period of 6-11 months (5-6\%). Energy from fruit was at a similar level throughout the transition period (6-7\% from 6 to 47 months) but energy from juice increased from $2 \%$ at $6-8$ months to $6 \%$ of daily energy from 15 months on.

\section{Milk and dairy products}

Breast milk and infant formula contributed $99.2 \%$ of the total energy from milk and dairy products at the age of $6-$ 8 months (Table 2). The proportion of energy from infant formula was $73 \%$ among these $6-8$ month olds, $26 \%$ from breast milk and just a small portion of energy coming from cow's milk $(<1 \%)$. At age 12-14 months, there was a large shift from formula and breast milk to cow's milk, with $60 \%$ of total milk energy coming from cow's milk. From the age of 12 months, the predominant milk source of energy was whole cow's milk, and by the age of 24 months, $53 \%$ of the cow's milk consumed was reduced fat or low-fat milk. Cheese and yogurt contributed little energy before the first year, but become more important sources of energy after 12 months, providing $21 \%$ of energy from milk and dairy products by 24 months of age.

\section{Grains}

Grains are generally the first food group to be introduced in the diets of infants, contributing a significant portion of daily energy. By $6-8$ months, grains provided $11 \%$ of daily energy, most of which was from infant cereal (Table 3). By 9-11 months, infants were getting $13 \%$ of energy from grains, with $40 \%$ of this contributed by infant cereals and the rest from a variety of grain products including all family (ready-to-eat and cooked) cereals, rice and pasta, and bread and rolls. Beginning from the age of 12-14 months, children consumed approximately $16 \%$ of total energy from grains, with the largest portion coming from all family cereals, followed by similar amounts from crackers and pretzels, rice and pasta, and bread and rolls. The selection of cereals shifted from primarily infant cereals before 12 months to all family cereals from 12 months onward. The all family cereals consumed by children 12-14 months were predominantly not pre-sweetened, but with a similar consumption of presweetened and not presweetened from 15 months. All family cereal consumed from 12 months were more often whole grain (71\% of energy from all family cereals) than not whole grain (29\%). At all ages, the vast majority of breads consumption was refined grain, not whole grain.

\section{Mixed dishes}

Mixed dishes accounted for $4 \%$ of daily energy at 6-8 months and $8 \%$ of daily energy at $9-11$ months (Table 4 ). Baby food dinners are the predominant type of mixed dish at 6-8 months and comprise about a third of the mixed dish energy at 9-11 months. Commercially prepared toddler dinners were consumed beginning at 9-11 months, and provided about 6\% energy from mixed dishes at 9-15 months with a lower consumption until 24 months. Grain based mixed dishes provided most of

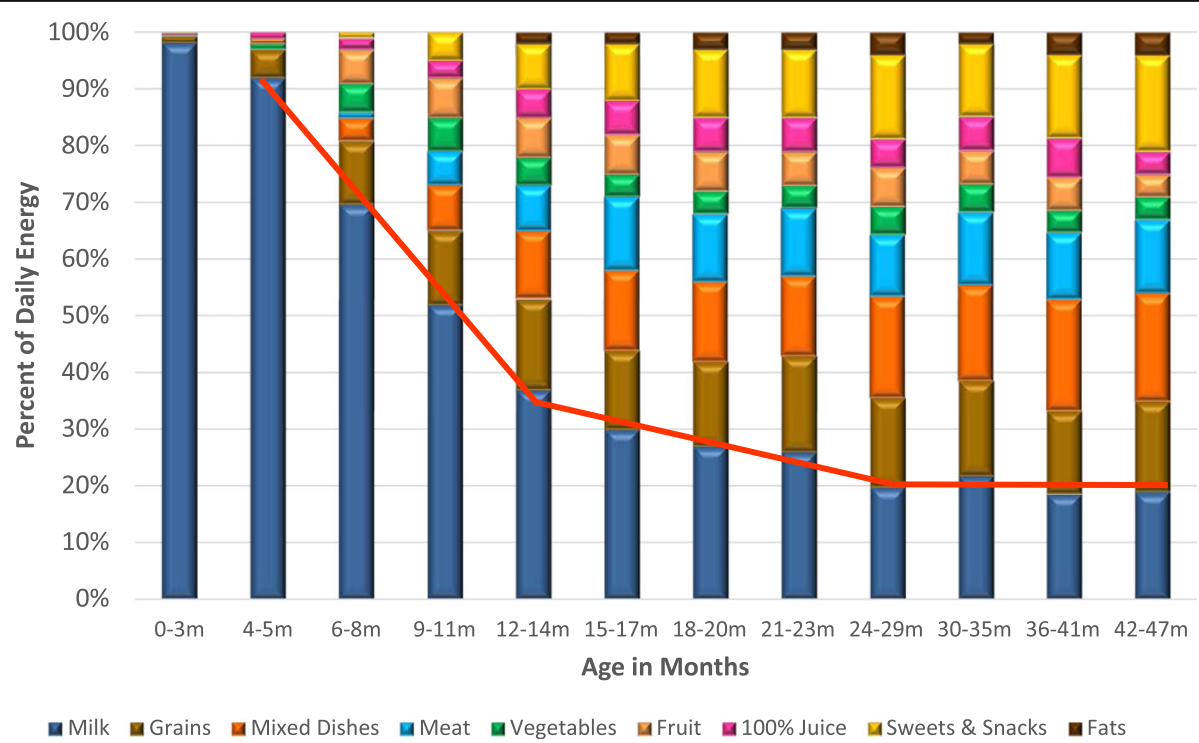

Fig. 1 Percent of energy from major food groups, as consumed, 0-48 months: FITS 2008. Very early in life, the diet transitions from an all milk diet to a diverse diet that is high in sweets and low in fruits and vegetables 


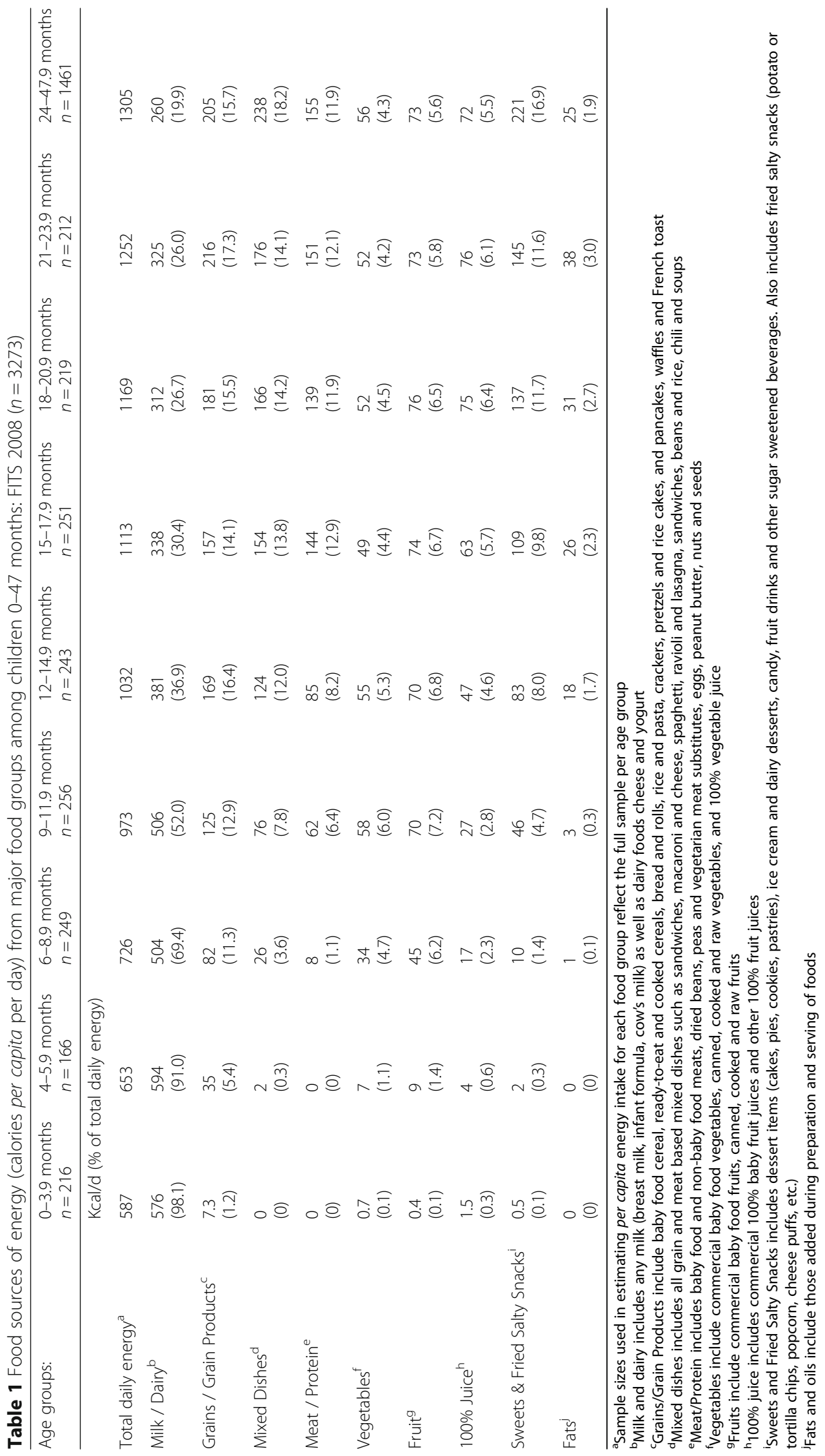


Table 2 Energy (calories per capita per day) from different types of Milk and Dairy products among children 6-47 months: FITS 2008 $(n=2891)$

\begin{tabular}{|c|c|c|c|c|c|c|c|}
\hline Age groups: & $\begin{array}{l}6-8.9 \text { months } \\
n=249\end{array}$ & $\begin{array}{l}\text { 9-11.9 months } \\
n=256\end{array}$ & $\begin{array}{l}12-14.9 \text { months } \\
n=243\end{array}$ & $\begin{array}{l}15-17.9 \text { months } \\
n=251\end{array}$ & $\begin{array}{l}18-20.9 \text { months } \\
n=219\end{array}$ & $\begin{array}{l}21-23.9 \text { months } \\
n=212\end{array}$ & $\begin{array}{l}24-47.9 \text { months } \\
n=1461\end{array}$ \\
\hline & $\mathrm{Kcal} / \mathrm{d}$ & & & & & & \\
\hline Total Energy Milk \& Dairy ${ }^{a}$ & 504 & 506 & 381 & 338 & 312 & 325 & 260 \\
\hline Milk & 496 & 485 & 345 & 294 & 260 & 265 & 205 \\
\hline Breast milk & 130 & 135 & 30 & 8 & 2 & 8 & 1 \\
\hline Infant formula & 362 & 317 & 98 & 27 & 5 & 3 & 1 \\
\hline Cow's milk $^{\mathrm{b}}$ & 4 & 33 & 207 & 244 & 240 & 251 & 195 \\
\hline Whole & 3 & 27 & 178 & 200 & 184 & 173 & 74 \\
\hline Reduced-fat & 0 & 5 & 28 & 42 & 50 & 64 & 85 \\
\hline Low and non-fat & 0 & 0 & 2 & 1 & 5 & 12 & 23 \\
\hline Dairy Foods & 7 & 21 & 37 & 44 & 53 & 60 & 54 \\
\hline Cheese & 2 & 9 & 12 & 25 & 26 & 34 & 27 \\
\hline Yogurt & 5 & 12 & 25 & 19 & 27 & 26 & 27 \\
\hline
\end{tabular}

${ }^{a}$ The mean energy at the Total Milk \& Dairy level may include food sub-categories that are not displayed separately. Food sub-categories displayed may not be mutually exclusive

${ }^{\mathrm{b}}$ Cow's milk also includes goat's milk

Table 3 Energy (calories per capita per day) from different types of Grains and Grain Products among children 6-47 months: FITS $2008(n=2891)$

\begin{tabular}{|c|c|c|c|c|c|c|c|}
\hline Age groups: & $\begin{array}{l}6-8.9 \text { months } \\
n=249\end{array}$ & $\begin{array}{l}9-11.9 \text { months } \\
n=256\end{array}$ & $\begin{array}{l}12-14.9 \text { months } \\
n=243\end{array}$ & $\begin{array}{l}15-17.9 \text { months } \\
n=251\end{array}$ & $\begin{array}{l}18-20.9 \text { months } \\
n=219\end{array}$ & $\begin{array}{l}21-23.9 \text { months } \\
n=212\end{array}$ & $\begin{array}{l}24-47.9 \text { months } \\
n=1461\end{array}$ \\
\hline & $\mathrm{Kcal} / \mathrm{d}$ & & & & & & \\
\hline $\begin{array}{l}\text { Total Energy Grains/Grain } \\
\text { Products }^{\mathrm{a}}\end{array}$ & 82 & 125 & 169 & 157 & 181 & 216 & 205 \\
\hline Infant cereals & 68 & 53 & 22 & 6 & 4 & 4 & 4 \\
\hline All Family cereals ${ }^{\mathrm{b}}$ & 3 & 27 & 52 & 44 & 58 & 55 & 61 \\
\hline Pre-sweetened ${ }^{c}$ & 0 & 13 & 16 & 22 & 24 & 29 & 31 \\
\hline Not-presweetened & 3 & 14 & 35 & 22 & 34 & 26 & 30 \\
\hline Whole grain $^{d}$ & 3 & 24 & 41 & 26 & 42 & 39 & 43 \\
\hline Refined grain & 0 & 3 & 11 & 18 & 15 & 16 & 17 \\
\hline Bread and rolls ${ }^{e, f}$ & 1 & 11 & 20 & 22 & 26 & 53 & 36 \\
\hline Whole grain ${ }^{d}$ & 0 & 3 & 6 & 6 & 5 & 6 & 6 \\
\hline Refined grain & 1 & 8 & 15 & 16 & 22 & 47 & 29 \\
\hline Rice and pasta ${ }^{9}$ & 1 & 15 & 23 & 27 & 35 & 28 & 32 \\
\hline Crackers, pretzels, rice cakes & 5 & 8 & 23 & 34 & 36 & 33 & 42 \\
\hline $\begin{array}{l}\text { Pancakes, waffles, French } \\
\text { toast }\end{array}$ & 1 & 3 & 12 & 12 & 10 & 29 & 21 \\
\hline
\end{tabular}

${ }^{a}$ The mean energy at the Total Grains/Grain Products level may include food sub-categories that are not displayed separately. Food sub-categories displayed may not be mutually exclusive

${ }^{\mathrm{b}}$ All family cereals include both ready-to-eat cereals and cooked cereals

'Pre-sweetened cereals are defined as those containing more than $21.2 \mathrm{~g}$ sugar per $100 \mathrm{~g}$

"Includes foods assigned to the "whole grain" subgroup in the NDS-R Food Servings Count System; it does not include foods assigned to the "some whole grain" subgroup

"Bread and rolls also includes biscuits, bagels and tortillas

${ }^{f}$ Bread and rolls excludes breads and rolls used in sandwiches-these are included as part of mixed dishes

${ }^{9}$ Rice and pasta excludes rice and pasta used in mixed dishes 
Table 4 Energy (calories per capita per day) from different types of Mixed Dishes among children 6-47 months: FITS 2008 ( $n=2891$ )

\begin{tabular}{|c|c|c|c|c|c|c|c|}
\hline Age groups: & $\begin{array}{l}6-8.9 \text { months } \\
n=249\end{array}$ & $\begin{array}{l}9-11.9 \text { months } \\
n=256\end{array}$ & $\begin{array}{l}12-14.9 \text { months } \\
n=243\end{array}$ & $\begin{array}{l}15-17.9 \text { months } \\
n=251\end{array}$ & $\begin{array}{l}18-20.9 \text { months } \\
n=219\end{array}$ & $\begin{array}{l}21-23.9 \text { months } \\
n=212\end{array}$ & $\begin{array}{l}24-47.9 \text { months } \\
n=1461\end{array}$ \\
\hline & $\mathrm{Kcal} / \mathrm{d}$ & & & & & & \\
\hline Total Energy Mixed Dishes ${ }^{a}$ & 26 & 76 & 124 & 154 & 166 & 176 & 238 \\
\hline Baby and Toddler dinners ${ }^{b}$ & 21 & 31 & 18 & 10 & 5 & 5 & 1 \\
\hline Macaroni and cheese & 3 & 8 & 18 & 36 & 26 & 38 & 32 \\
\hline Spaghetti, ravioli, lasagna & 1 & 11 & 21 & 30 & 29 & 39 & 29 \\
\hline Sandwiches & 0 & 8 & 37 & 32 & 58 & 37 & 98 \\
\hline Pizza & 0 & 2 & 6 & 26 & 9 & 22 & 33 \\
\hline Bean mixtures, chilic & 0 & 0 & 0 & 2 & 1 & 1 & 1 \\
\hline Soup & 0 & 6 & 7 & 9 & 9 & 10 & 12 \\
\hline
\end{tabular}

${ }^{a}$ The mean energy at the Total Mixed Dishes level may include food sub-categories that are not displayed separately. Food sub-categories displayed may not be mutually exclusive

${ }^{b}$ Baby and Toddler dinners are commercially prepared foods specifically for young children

'Includes beans and rice, chili prepared with beans, and other bean mixtures

energy from mixed dishes from 12 months and contributed over $80 \%$ of energy from mixed dishes from 15 months on. Sandwiches made up a key portion of this, providing $25-47 \%$ of energy from grain-based mixed dishes, depending on age. Macaroni and cheese as well as the category of spaghetti, lasagna and ravioli each accounted for more than 20\% of energy from grain-based mixed dishes among toddlers 12-24 months and about $15 \%$ after 24 months.

\section{Meats}

Poultry (chicken and/or turkey) was the top meat/protein source of calories, followed by processed meats (hotdogs, sausages and cold cuts), and eggs (Table 5). Chicken and turkey provided 34\% of total energy from meats at 9-11 months of age and then quickly increased to $37-48 \%$ of total energy from meat between 12 and 47 months, almost double that of other protein sources. Aside from processed meats (hot dogs, sausages and cold cuts), there was little consumption of beef or pork among infants and toddlers, and few reported consuming dried beans and peas or other legumes.

\section{Vegetables}

Vegetables were generally introduced into the diet of infants beginning at 6 months, and consumption was highest ( $6 \%$ of daily energy) during the 9-11 month period (Table 6). From the age of 12 -months, vegetables contributed only $4-5 \%$ of total daily energy.

Large and important shifts in amount and type of vegetable intake happened between infancy and toddlerhood. At 6-8 months more calories were coming from deep yellow vegetables, including carrots, winter squashes and sweet potato, than from any other vegetable. By the age of 9-11 months more calories were coming from green vegetables, followed by deep yellow, white potatoes and other vegetables. By 12-14 months, white potatoes (including French fries and other fried potatoes) were the most commonly consumed vegetable, contributing more than half of the daily energy from vegetables, and this pattern continued through 47 months of age.

Given the shift to higher calorie types of vegetables (French fries and other white potatoes), we also assessed the amount of vegetables consumed as discrete items in order to more clearly understand vegetable consumption (Fig. 2). While the mean calories from vegetables remained constant at 56-58 kcal between 9 and 47 months (Table 6), the mean amount consumed (grams per capita per day) declined. At age 9-11 months, children consumed more total vegetables than at any other age that was studied $(92 \mathrm{~g})$. By the time children reached 12 months of age, the amount of vegetables consumed declined to $64 \mathrm{~g}$ per day and remained at this level through 47 months.

The form of the vegetables also shifted dramatically between 6 and 14 months. Baby food vegetables were highest at 6-8 months, contributing more than $75 \%$ of the vegetable calories, and dropped to $30 \%$ of vegetable calories at 9-11 months, and $15 \%$ of vegetable calories at 12-14 months. However, given the higher calorie vegetables being consumed after 9 months, the total amount of vegetables from baby food was $45 \%$ and $30 \%$ at 9-11 months and 12-14 months respectively.

\section{Fruit and $100 \%$ juice}

Fruits were also commonly introduced to infants at around 6 months of age, and by 9 months, infants and toddlers consumed about 70 cal of fruits per day (Table 7). Baby food fruits contributed $75 \%$ of the fruit calories at 6-8 months, half the fruit calories at 9-11 months, and about $15 \%$ at $12-14$ months. Fresh fruits 
Table 5 Energy (calories per capita per day) from different types of Meats and Protein sources among children 6-47 months: FITS $2008(n=2891)$

\begin{tabular}{|c|c|c|c|c|c|c|c|}
\hline Age groups: & $\begin{array}{l}6-8.9 \text { months } \\
n=249\end{array}$ & $\begin{array}{l}9-11.9 \text { months } \\
n=256\end{array}$ & $\begin{array}{l}12-14.9 \text { months } \\
n=243\end{array}$ & $\begin{array}{l}15-17.9 \text { months } \\
n=251\end{array}$ & $\begin{array}{l}18-20.9 \text { months } \\
n=219\end{array}$ & $\begin{array}{l}21-23.9 \text { months } \\
n=212\end{array}$ & $\begin{array}{l}24-47.9 \text { months } \\
n=1461\end{array}$ \\
\hline & $\mathrm{Kcal} / \mathrm{d}$ & & & & & & \\
\hline Total Energy Meats/Protein ${ }^{a}$ & 8 & 62 & 85 & 144 & 139 & 151 & 155 \\
\hline Baby food meat & 3 & 1 & 2 & 1 & 0 & 0 & 0 \\
\hline Non-baby food meat & 4 & 52 & 57 & 99 & 98 & 115 & 116 \\
\hline Eggs & 0 & 7 & 11 & 34 & 28 & 19 & 22 \\
\hline Peanut butter, nuts, seeds & 0 & 2 & 2 & 2 & 3 & 7 & 11 \\
\hline $\begin{array}{l}\text { Dried beans, peas, } \\
\text { vegetarian meat substitutes }\end{array}$ & 1 & 1 & 12 & 9 & 11 & 10 & 8 \\
\hline \multicolumn{8}{|l|}{ Types of Meat ${ }^{\mathrm{b}}$} \\
\hline Chicken/turkey & 4 & 18 & 22 & 48 & 43 & 43 & 54 \\
\hline $\begin{array}{l}\text { Hot dogs, sausage, } \\
\text { cold cuts }\end{array}$ & 1 & 9 & 18 & 21 & 23 & 36 & 28 \\
\hline Beef & 0 & 1 & 6 & 21 & 15 & 15 & 16 \\
\hline Pork/ham & 1 & 2 & 3 & 4 & 13 & 12 & 9 \\
\hline Fish/shellfish & 0 & 1 & 4 & 3 & 4 & 6 & 6 \\
\hline Other meats & 0 & 21 & 5 & 3 & 1 & 2 & 3 \\
\hline
\end{tabular}

${ }^{a}$ The mean energy at the Total Meat/Protein level may include food sub-categories that are not displayed separately. Food sub-categories displayed may not be mutually exclusive

bIncludes baby and non-baby food meats

Table 6 Energy (calories per capita per day) from different types of Vegetables among children 6-47 months: FITS 2008 ( $n=2891$ )

\begin{tabular}{|c|c|c|c|c|c|c|c|}
\hline Age groups: & $\begin{array}{l}6-8.9 \text { months } \\
n=249\end{array}$ & $\begin{array}{l}9-11.9 \text { months } \\
n=256\end{array}$ & $\begin{array}{l}12-14.9 \text { months } \\
n=243\end{array}$ & $\begin{array}{l}15-17.9 \text { months } \\
n=251\end{array}$ & $\begin{array}{l}18-20.9 \text { months } \\
n=219\end{array}$ & $\begin{array}{l}21-23.9 \text { months } \\
n=212\end{array}$ & $\begin{array}{l}24-47.9 \text { months } \\
n=1461\end{array}$ \\
\hline & \multicolumn{7}{|l|}{$\mathrm{Kcal} / \mathrm{d}$} \\
\hline Total Energy Vegetables ${ }^{a}$ & 34 & 58 & 55 & 49 & 52 & 52 & 56 \\
\hline Baby food vegetables & 26 & 17 & 9 & 4 & 2 & 1 & 0 \\
\hline Cooked vegetables ${ }^{\mathrm{b}}$ & 8 & 40 & 46 & 43 & 49 & 47 & 51 \\
\hline \multicolumn{8}{|l|}{ Types of vegetables ${ }^{c}$} \\
\hline Dark green $^{d}$ & 0 & 15 & 2 & 1 & 4 & 1 & 3 \\
\hline Deep yellow ${ }^{e}$ & 16 & 13 & 11 & 5 & 4 & 2 & 5 \\
\hline White potatoes & 5 & 13 & 32 & 27 & 29 & 27 & 32 \\
\hline $\begin{array}{l}\text { French fries/fried } \\
\text { potatoes }\end{array}$ & 0 & 4 & 15 & 9 & 17 & 16 & 23 \\
\hline Other starchy vegetables ${ }^{f}$ & 6 & 6 & 5 & 9 & 6 & 13 & 8 \\
\hline $\begin{array}{l}\text { Other reported } \\
\text { vegetables }^{9}\end{array}$ & 7 & 11 & 6 & 7 & 9 & 8 & 9 \\
\hline \multicolumn{8}{|c|}{$\begin{array}{l}\text { } \text { The mean energy at the Total Vegetables level may include food sub-categories (like } 100 \% \text { vegetable juice) that were consumed in small quantities and are not } \\
\text { displayed separately. Food sub-categories displayed may not be mutually exclusive } \\
\text { bIncludes any type of cooked vegetable from canned, fresh or frozen } \\
\text { cIncludes commercial baby food, cooked vegetables and raw vegetables } \\
\text { dIncludes broccoli, spinach and other greens, and romaine lettuce } \\
\text { eIncludes carrots, pumpkin, sweet potatoes and winter squash } \\
\text { fIncludes corn, green peas, immature lima beans, black-eyed peas (not dried), cassava, and rutabaga } \\
\text { Includes artichoke, asparagus, beets, Brussels sprouts, cabbage, cauliflower, celery, cucumber, eggplant, green beans, lettuce, mushrooms, okra, onions, pea pods, }\end{array}$} \\
\hline
\end{tabular}




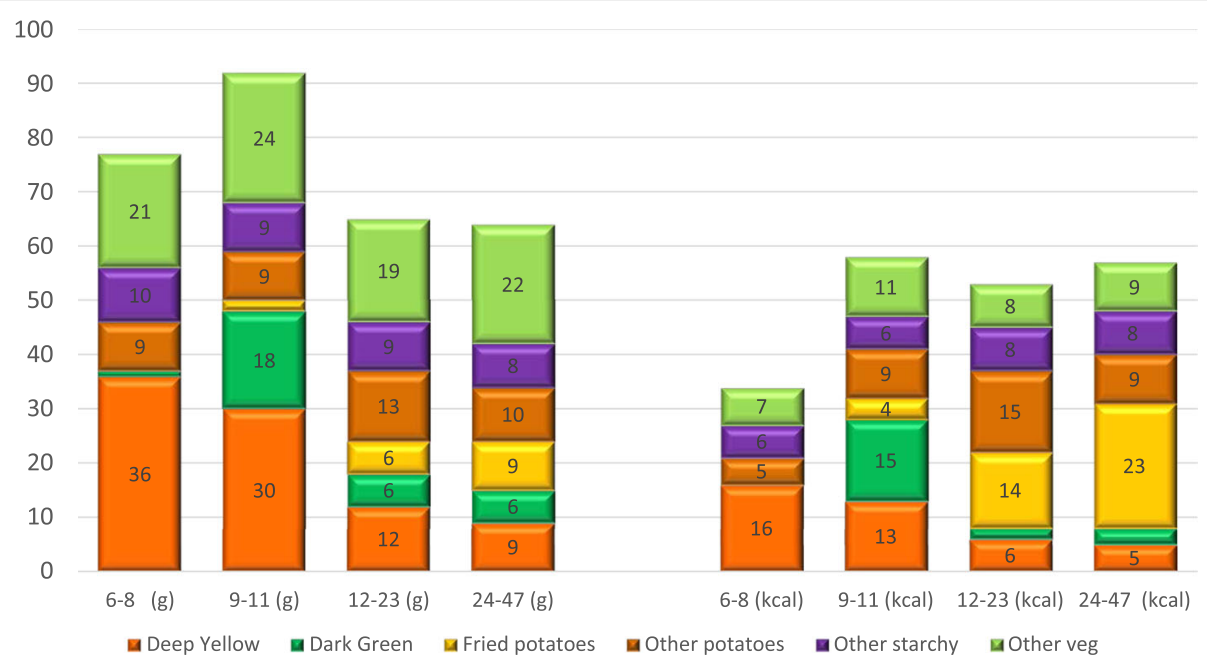

Fig. 2 Grams vs Kcal of various types of vegetables consumed, 0 to 48 months: FITS 2008. From about 12 months, total amount of vegetables consumed declines and higher calorie vegetables begin to replace lower calorie vegetables

Table 7 Energy (calories per capita per day) from different types of Fruit among children 6-47 months: FITS $2008(n=2891)$

\begin{tabular}{|c|c|c|c|c|c|c|c|}
\hline Age groups: & $\begin{array}{l}6-8.9 \text { months } \\
n=249\end{array}$ & $\begin{array}{l}9-11.9 \text { months } \\
n=256\end{array}$ & $\begin{array}{l}12-14.9 \text { months } \\
n=243\end{array}$ & $\begin{array}{l}15-17.9 \text { months } \\
n=251\end{array}$ & $\begin{array}{l}18-20.9 \text { months } \\
n=219\end{array}$ & $\begin{array}{l}21-23.9 \text { months } \\
n=212\end{array}$ & $\begin{array}{l}24-47.9 \text { months } \\
n=1461\end{array}$ \\
\hline & $\mathrm{Kcal} / \mathrm{d}$ & & & & & & \\
\hline Any Fruit or Juice & 62 & 97 & 117 & 136 & 151 & 148 & 145 \\
\hline Any Fruit & 45 & 70 & 70 & 74 & 76 & 73 & 73 \\
\hline Baby food fruit & 34 & 35 & 11 & 7 & 7 & 1 & 0 \\
\hline Canned fruit & 2 & 9 & 20 & 17 & 19 & 25 & 12 \\
\hline Fresh or frozen fruit & 9 & 26 & 34 & 46 & 43 & 42 & 54 \\
\hline \multicolumn{8}{|l|}{ Types of Fruit ${ }^{b}$} \\
\hline Apples & 14 & 16 & 12 & 15 & 13 & 16 & 19 \\
\hline Bananas & 22 & 28 & 24 & 24 & 18 & 19 & 20 \\
\hline Berries & 0 & 1 & 3 & 4 & 3 & 1 & 4 \\
\hline Citrus fruits & 0 & 3 & 3 & 2 & 5 & 2 & 4 \\
\hline Grapes & 0 & 1 & 5 & 5 & 8 & 7 & 7 \\
\hline Melons & 0 & 1 & 3 & 1 & 2 & 1 & 2 \\
\hline $100 \%$ fruit juice ${ }^{c}$ & 17 & 27 & 47 & 63 & 75 & 76 & 72 \\
\hline Apple/apple blend & 8 & 16 & 21 & 33 & 35 & 23 & 34 \\
\hline Grape & 4 & 6 & 5 & 9 & 11 & 18 & 8 \\
\hline Citrus/citrus blend & 1 & 1 & 10 & 9 & 8 & 11 & 15 \\
\hline Other $^{d}$ & 4 & 4 & 11 & 12 & 21 & 24 & 15 \\
\hline Sample size & 249 & 256 & 243 & 251 & 219 & 212 & 1461 \\
\hline
\end{tabular}

${ }^{a}$ The mean energy at the Total Fruits level may include food sub-categories that were consumed in small quantities and are not displayed separately. Food subcategories displayed may not be mutually exclusive

Includes all baby food and non-baby food fruits

'Includes all $100 \%$ fruit juice (baby and non-baby)

${ }^{d}$ Includes all other $100 \%$ fruit juices including single juice types and blends 
were the key contributors, with most of the calories from fruit coming from bananas and apples.

There is very little juice consumption before 6 months of age (Table 1). Fruit juice provided $2-3 \%$ of calories for 6-11 month olds and it increased to almost 5\% at $12-14$ months and about $6 \%$ of total calories from 15 to 47 months. The predominant type of juice among infants and toddlers was apple juice or apple juice blends.

\section{Sweets, sweetened beverages and fried salty snacks}

Sweets, sweetened beverages and fried salty snacks were introduced early and quickly became a major source of calories reaching $13 \%$ of daily energy by the end of the second year (21-23 months) and almost 17\% of total energy by $24-47$ months (Table 8 , Fig. 3 ). The majority of these calories were from sweets, with fried salty snacks (including potato and tortilla chips, popcorn and cheese puffs/curls, etc.) making up very little of this energy, being virtually not consumed in the first year, $1 \%$ of total calories in the second year and reaching about $2 \%$ of calories by 24-47 months. Cakes, pies, cookies and pastries along with sweetened beverages were the leading contributors of calories among these discretionary foods. Cookies were the biggest contributor in this category, providing 20-35 cal in the second year of life and $40 \mathrm{cal}$ at 24-47 months. Consumption of sweetened beverages increased from $15 \mathrm{cal}$ at $9-11$ months to $35 \mathrm{cal}$ by the end of the second year and $52 \mathrm{cal}$ per capita per day at 24-47 months, with fruit flavored drinks providing most of these calories.

\section{Discussion}

As children grow and consume more calories to support normal growth, development and activity, it is critical that the calories they consume are quality calories and the food patterns built are healthy patterns that will support growth while helping to prevent childhood obesity and chronic disease later in life. Findings from the FITS 2008 reported here build on those reported earlier [16, 18] by further elaborating the relative contributions of different foods to total energy intake.

Human breast milk is recommended as the sole source of nutrients for infants up to approximately 6 months of age [25] and iron-fortified infant formulas are the most appropriate substitute when breast milk is not available [25]. The American Academy of Pediatrics (AAP) does not recommend introduction of cow's milk until after the age of 12 months. We found that, while there was far less breast feeding than recommended, most infants consumed appropriate types of milk (breast milk or iron-fortified infant formula) up to the age of 12 months, with very little whole cow's milk being consumed during infancy. There was an appropriate switch to whole milk after 12 months, in line with AAP recommendations
[25]. While there was a shift to more consumption of reduced fat milks ( $2 \%$ milk fat) after 2 years of age, there was little consumption of low fat milks (1\% milk fat or skimmed milk). These FITS results are very similar to findings from NHANES, which report only approximately 3\% of total daily energy from cow's milk from 6 to 11 months of age, increasing to $22.4 \%$ from 12 to 23 months [20]. Also in the second year of life, cow's milk is providing $47 \%$ of saturated fat [20].

At the age of 4-6 months, infants need to begin to consume iron-rich complementary foods or dietary supplements [25] and for this reason, infant cereals in the US are fortified with iron and are included in the Special Supplemental Nutrition Program for Women, Infants, and Children (WIC). Previous FITS research has shown that overall $80 \%$ of infants $6-8$ months old consume fortified infant cereal [18], and the rate is higher among WIC participants [19], so it is not surprising that infant cereal consumption was highest among this age group. However, we observed a shift to all-family cereals beginning at 9 months, and many all-family cereals can be much lower in iron than infant cereals. With $12 \%$ of $6-$ 11 month old infants having inadequate iron intake [17], and rates of iron deficiency anemia in the range of 0.9 $4.4 \%$ among toddlers [26], there is a need for ironfortified cereals and meats (as a source of heme iron) in the diet of young children $[2,25]$.

In addition to grains, a major portion of the increase in calories that children consume between infancy and preschool are contributed by mixed dishes, especially grain-based mixed dishes. With the large portion of calories coming from mixed dishes, it is important for these to be made with healthy ingredients such as lean meats, whole grains and vegetables and to be low in sodium. In fact, mixed dishes are responsible for almost $40 \%$ of total vegetable intake in children ages $2-5$ years [27]. The overall vegetable intake was somewhat higher than those we reported only from vegetables consumed as distinct food items [16], but still falling far below the recommendations for most children.

The contribution of different foods to energy intake is an important way to assess diets, but may provide fewer insights for vegetables. Therefore for vegetables, in addition to the energy contribution, we also assessed amount consumed. This analysis revealed that infants between 9 and 11 months of age are consuming more vegetables, in absolute gram amounts, than they will consume at any other age in childhood. Children consume a similar number of calories from vegetables at 12 months that they continue to consume until age 47 months, even though they add about an additional $400 \mathrm{kcal}$ to their daily energy intake during this period. Not only is there less vegetable consumption overall (as a percentage of total energy), there is also less consumption 


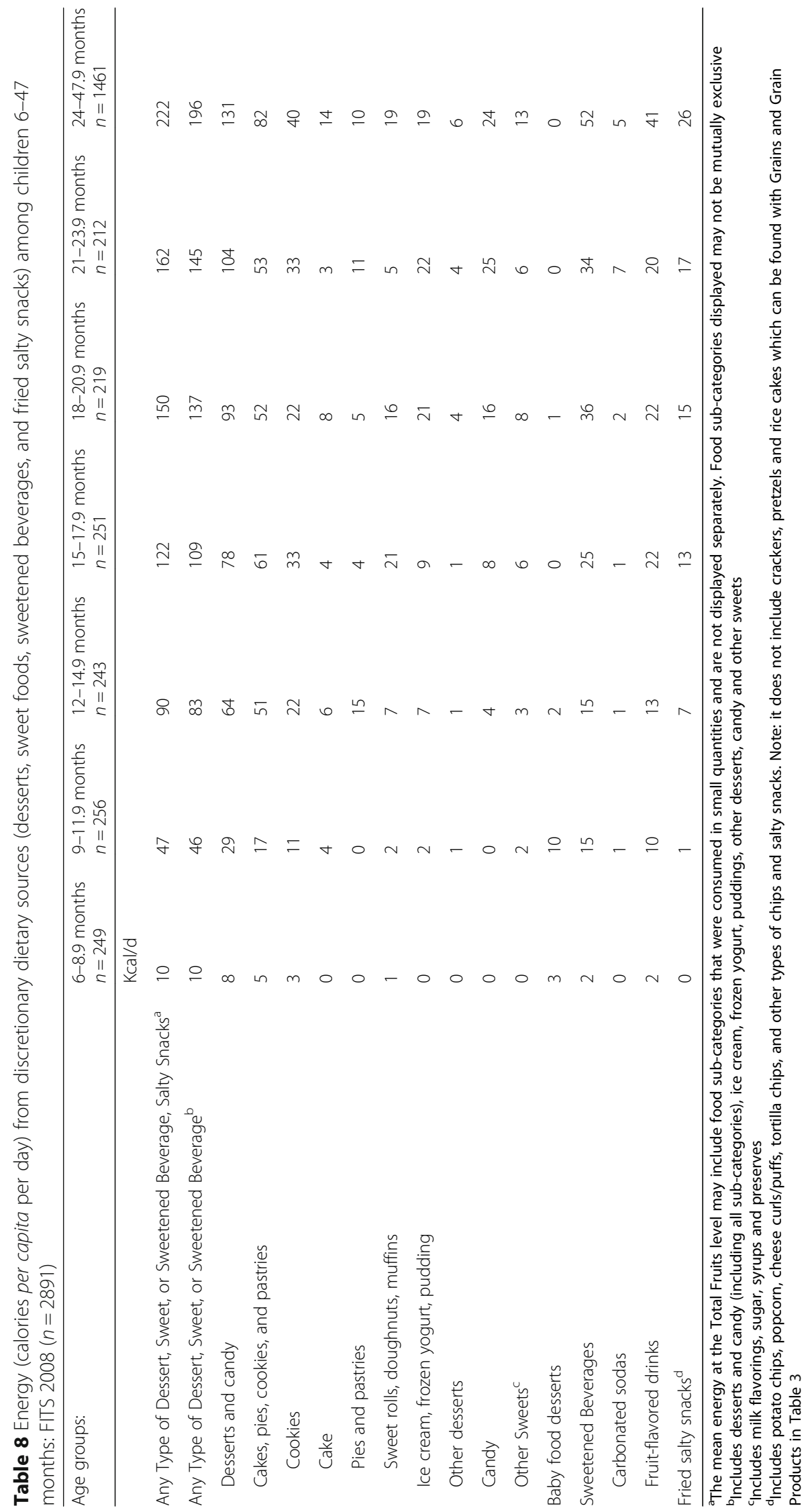




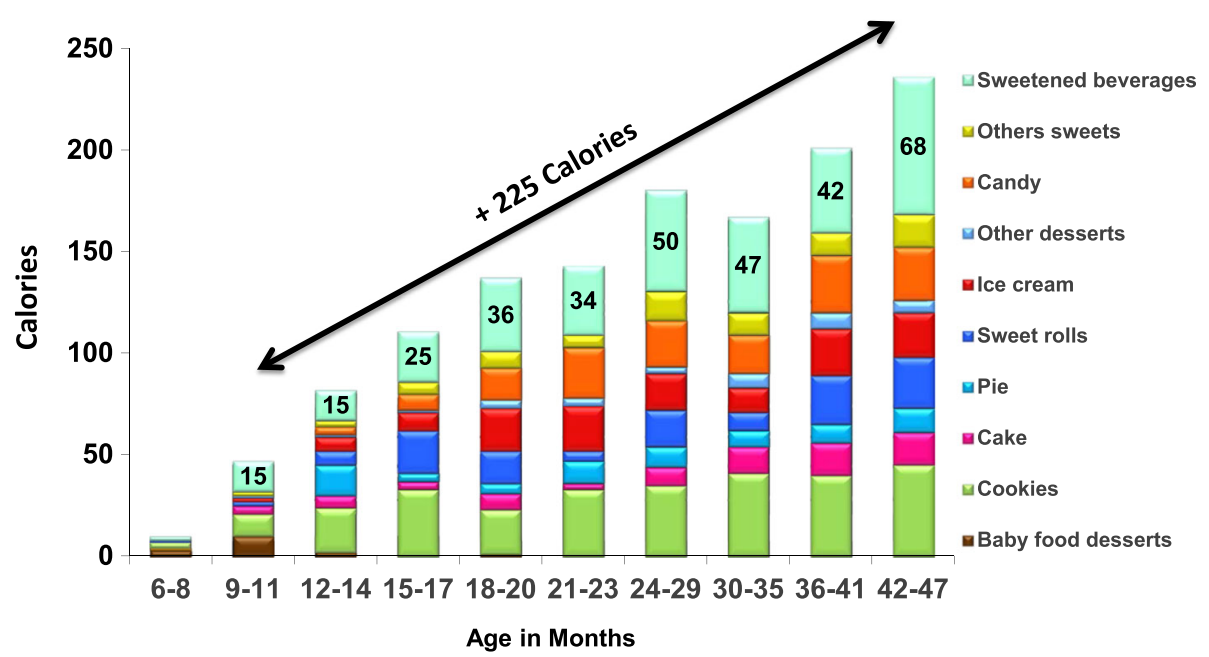

Fig. 3 Energy intake from sweets and sweetened beverages, 0 to 48 months: FITS 2008. More than a third of the 600 cal increase in energy intake seen between 6 months and 4 years comes from sweets and sweetened beverages

of nutrient rich deep yellow and green vegetables and higher consumption of white potatoes, especially French fries, after infancy. It appears that this is related to several factors. First, baby food vegetable consumption is declining and it does not appear to be replaced, or not completely replaced with cooked vegetables. Secondly, it appears that there is less variety in the vegetables offered to children as they grow older. This analysis evaluated discrete servings of vegetables, so it is also likely that more vegetables are being consumed as part of mixed dishes. Infants accept a wide variety of vegetables, especially after repeated exposures [28]. Frequency of infant vegetable intake has also been associated with intake at 6 years of age [9]. Taken together, there is a big opportunity to continue the positive trend of infant vegetable intake and acceptance into childhood.

Similar to the pattern seen for vegetables, the amount of fruit consumption in children up to age 47 months is established by $9-11$ months at about $70 \mathrm{cal}$, which is the equivalent of about one cup of chopped apples or one half cup of sliced banana [29]. Calories from 100\% fruit juice continue to increase into toddlerhood until at 2-4 years, the number of calories from 100\% fruit juice (72 kcal) is equivalent to about $5 \mathrm{oz}$ of unsweetened apple juice [29]. In line with AAP recommendations at the time [2], few infants in our study consumed juice before the age of 6 months. Analysis from NHANES [20] shows that $100 \%$ juice contributes more calories $(5.9 \%$ of daily energy) than fruits (4.8\% of daily energy) for children 12-23 months, but this may be due to the fact that some of these data are older (beginning with the 20052006 NHANES release) and we have seen a change to less juice consumption between FITS 2002 and 2008 [18]. Our results show similar energy from fruits and
$100 \%$ fruit juices from the age of 18 months, while for infants and younger children, fruit is more commonly consumed. Fruit intake and variety in infancy has been shown to be predictive of fruit consumption at 6-8 years of age [11], so establishing this habit early has lasting implications for diet composition.

The total daily intake of calories among young children increases by about $600 \mathrm{cal}$ between ages 6 months and 4 years, from about 700 to about $1300 \mathrm{cal}$ per day. About one-third of these additional calories comes from sweets and sweetened beverages, accounting for $15 \%$ of total daily energy at 24-47 months. Among younger children, 12-23 months old, sweets and sweetened beverages provided $10.4 \%$ of total daily energy, and although the food groups were slightly different, this is similar to the $10.2 \%$ daily energy from sweetened foods and beverages reported in NHANES for the same ages [20]. Early consumption of sugar sweetened beverages is problematic not only by displacing more energy dense foods [2], but also because early consumption of sugar sweetened beverages significantly increases the likelihood of consuming them later in childhood [12], along with higher odds of developing obesity [30]. High consumption of discretionary calorie foods contributes to two significant public health problems, overconsumption of energy as well as inadequate intake of healthy foods from the basic food groups, such as vegetables, fruits and whole grains, and their associated nutrients [2]. Shifting the consumption from sweets to fruits and vegetables would likely provide fewer calories and more dietary fiber and potassium, nutrients previously shown to be generally inadequate in young children's diets [17], as well as antioxidant vitamins A, C, and E.

The FITS 2008 is a large-scale, nationally representative study using robust methods for dietary data collection and 
analysis. The food classification system is similar to that used by USDA for NHANES [31], but re-grouped certain foods to better reflect the diet patterns of infants and toddlers [14]. However, because foods were classified as consumed, this approach may undercount some specific foods of interest, such as vegetables, by not including those found in mixed dishes. Other limitations include the possibility of over- or under-reporting by the parent or other proxy reporter for their child's daily intake. Finally, in order to analyze by several age groups and numerous food groups to understand changes in food and energy consumption across the various ages, the resulting sample in some cells was quite low. Therefore, the occasional point estimate that is not in line with the trend may need to be interpreted with caution.

\section{Conclusions}

These findings from FITS 2008 highlight the first 2 years of life as the most dynamic period in the exposure and introduction of food groups to infants' diets. The fast rate of increase in energy contributed by foods and beverages between 4 and 14 months of age, decreases from 15 to 24 months, after which the relative energy contribution by food group remains remarkably stable despite increases in absolute energy intake. This suggests this early feeding period is a highly significant time for development of dietary patterns and potentially for subsequent eating habits. These findings also provide further insight and highlight the need to address issues in toddler nutrition and feeding that have been previously identified, key among which are high sweet and low vegetable consumption. There has been much more focus on appropriate feeding during infancy and while there is still room for improvement, we do see a more positive picture of diet during infancy. We need an urgent call to action for focus on research on educational approaches and development of actionable feeding guidance for parents and caregivers to foster healthy feeding practices, to help shape the child's diet patterns and preferences until they transition to the family table.

\section{Abbreviations \\ AAP: American Academy of Pediatrics; FITS: Feeding Infants and Toddlers Study; NDSR: Nutrition Data System for Research; NHANES: National Health and Nutrition Examination Survey; SAS: Statistical Analysis System; US: United States; USDA: United States Department of Agriculture; WIC: Special Supplemental Nutrition Program for Women, Infants, and Children}

\section{Acknowledgements}

Not applicable.

\section{Funding}

This research was funded by Nestle R\&D.

\section{Availability of data and materials}

The Feeding Infants and Toddlers Study (FITS) 2008 data is not publicly available, but may be available from the author upon reasonable request, with approval of the ownership organization (Nestle R\&D).

\section{Competing interests}

Authors Reidy, Deming, Eldridge and Saavedra are employed by Nestle, Briefel and Fox are employed by Mathematica Policy Research.

\section{Authors' contributions}

KR contributed to the design of the study and data analysis, interpretation of the data, writing of the manuscript, DD contributed to the design of the study and data analysis, interpretation of the data, critical review of the manuscript, RB contributed to the design of the study and data analysis, and critical review of the manuscript, MKF contributed to the design of the study and data analysis, and critical review of the manuscript, JS contributed to the interpretation of the data and critical review of the manuscript, AE contributed to the interpretation of the data and manuscript writing. All authors read and approved the final manuscript.

Consent for publication

Consent was received from Nestle R\&D management.

\section{Ethics approval and consent to participate}

All instruments and procedures are available on-line [23] and include the questionnaires for the 1) recruitment interview, 2) dietary interview for children $<24$ months, and 3) dietary interview for children $>24$ months, as well as the child care food information form (to be sent to day care for recording foods eaten there), and two tools to help the interviewee more accurately report amounts of foods and beverages consumed 1) instructions for measuring the cup that the child routinely drinks from and 2) the food measurement guide with pictures of various types of foods. All were reviewed and approved by Mathematica Policy Research's independent institutional review board at the time of the study (Public/Private Ventures, Philadelphia, PA).

\section{Author details}

${ }^{1}$ Nestle Infant Nutrition, Global R and D, 12 Vreeland Road, Florham Park, NJ 07932, USA. ${ }^{2}$ Mathematica Policy Research, 1100 1st Street, N.E, Washington, DC 20002, USA. 'Mathematica Policy Research, 955 Massachusetts Avenue, Cambridge, MA 02138, USA. ${ }^{4}$ Nestlé Nutrition, Rue Entre-deux-Villes 10, 1814 La Tour-de-Peilz, Switzerland. ${ }^{5}$ Nestle Research Center, Route du Jorat 57, Vers-chez-les-Blanc, 1000 Lausanne-26, Switzerland.

Received: 29 July 2016 Accepted: 23 December 2016

Published online: 10 January 2017

\section{References}

1. Schwartz C, Scholtens PAMJ, Lalanne A, Weenen H, Nicklaus S. Development of health eating habits early in life. Review of recent evidence and selected guidelines. Appetite. 2011;57:796-807.

2. Young B, Krebs N. Complementary feeding: critical considerations to optimize growth, nutrition and feeding behavior. Curr Pediatr Rep. 2013;1:247-56.

3. Ventura AK, Birch LL. Does parenting affect children's eating and weight status? Intl J Behav Nutr Phys Act. 2008:5:15. doi:10.1186/1479-5868-5-15.

4. Birch LL, Doub AE. Learning to eat: birth to age 2 y. Am J Clin Nutr. 2014;99: 723S-8S.

5. Birch LL, Ventura AK. Preventing childhood obesity: what works? Int J Obes. 2009:33:S74-81.

6. Clark HR, Goyder E, Bissell P, Blank L, Peters J. How do parents' child-feeding behaviours influence child weight? implications for childhood obesity policy. J Public Health. 2007;29:132-41.

7. Dattilo AM, Birch L, Krebs NF, Lake A, Taveras EM, Saavedra JM. Need for early interventions in the prevention of pediatric overweight: A review and upcoming directions. J Obesity, 2012; http://dx.doi.org/10.1155/2012/123023.

8. Roy SM, Spivack JG, Faith MS, Cesi A, Mitchell JA, Kelly A, Grant SFA, McCormack SE, Zemel BS. Infant BMI or weight-for-length and obesity risk in early childhood. Pediatrics. 2016;137:e20153492.

9. Grimm KA, Kim SA, Yaroch AL, Scanlon KS. Fruit and vegetable intake during infancy and early childhood. Pediatrics. 2014;134:S63-9.

10. Mallan KM, Fildes A, Magarey AM, Daniels LA. The relationship between number of fruits, vegetables, and noncore foods tried at age 14 months and food preferences, dietary intake patterns, fussy eating behavior, and weight status at age 3.7 years. J Acad Nutr Diet. 2016;116:630-7.

11. Skinner JD, Carruth BR, Bounds W, Ziegler PJ. Children's food preferences: a longitudinal analysis. J Am Diet Assoc. 2002;102:1638-47. 
12. Park $S$, Pan $L$, Sherry B, Li R. The association of sugar-sweetened beverage intake during infancy sugar-sweetened beverage intake at 6 years of age. Pediatrics. 2014;134:S56-62.

13. Devaney B, Ziegler P, Pac S, Karwe V, Barr SI. Nutrient intakes of infants and toddlers. J Am Diet Assoc. 2004;104:S14-21.

14. Fox MK, Pac S, Devaney B, Jankowski L. Feeding infants and toddlers study: what foods are infants and toddlers eating? J Am Diet Assoc. 2004;104:S22-30.

15. Fox MK, Reidy K, Novak T, Zeigler P. Sources of energy and nutrients in the diets of infants and toddlers. J Am Diet Assoc. 2006;106:S28-42.

16. Fox MK, Condon E, Briefel RR, Reidy KC, Deming DM. Food consumption patterns of young preschoolers: are they starting off on the right path? J Am Diet Assoc. 2010;110:S52-9.

17. Butte NF, Fox MK, Briefel RR, Siega-Riz AM, Dwyer JT, Deming DM, Reidy KC. Nutrient intakes of U.S. infants, toddlers, and preschoolers meet or exceed dietary reference intakes. J Am Diet Assoc. 2010;110:S27-37.

18. Siega-Riz AM, Deming DM, Reidy KC, Fox MK, Condon E, Briefel RR. Food consumption patterns of infants and toddlers: where are we now? J Am Diet Assoc. 2010;110:S38-51.

19. Deming DM, Briefel RR, Reidy KC. Infant feeding practices and food consumption patterns of children participating in WIC. J Nutr Educ Behav. 2014;46:S29-37.

20. Grimes CA, Szymlek-Gay EA, Campbell KJ, Nicklas TA. Food sources of total energy and nutrients among U.S. infants and toddlers: national health and nutrition examination survey 2005-2012. Nutrients. 2015;7:6797-836. doi:10. 3390/nu7085310.

21. Briefel RR, Kalb LM, Condon E, Deming DM, Clusen NA, Fox MK, Harnack L Gemmill E, Stevens M, Reidy KC. The feeding infants and toddlers study 2008: study design and methods. J Am Diet Assoc. 2010;110:S16-26.

22. Devaney B, Kalb L, Briefel R, Zavitsky-Novak T, Clusen N, Ziegler P. Feeding infants and toddlers study: overview of the study design. J Am Diet Assoc. 2004;104:S8-S13.

23. Nestlé Feeding Infants and Toddlers Study (FITS). https://medical.gerber.com/ nestle-science/feeding-infants-and-toddlers-study. Accessed 5 July 2016.

24. Nelson M, Bingham SA. Assessment of food consumption and nutrient intake. In: Design Concepts in Nutritional Epidemiology, Second Ed. (Margetts BM and Nelson M, eds.). New York: Oxford University Press; 1997. p. 123-69.

25. American Academy of Pediatrics Committee on Nutrition. Pediatric Nutrition, (Kleinman, RE, Greer FR, eds.). 7th ed. Elk Grove Village: American Academy of Pediatrics; 2014.

26. Baker RD, Greer FR, Committee on Nutrition. Diagnosis and prevention of iron deficiency and iron-deficiency anemia in infants and young children (0-3 years of age). Pediatrics. 2010;126:1040-50.

27. Branum $A M$, Rossen $L M$. The contribution of mixed dishes to vegetable intake among US children. Public Health Nutr. 2013;17:2053-60.

28. Mennella JA, Trabulski JC. Complementary foods and flavor experiences: setting the foundation. Ann Nutr Metab. 2012;60 Suppl 2:40-50

29. USDA National Nutrient Database for Standard Reference (Release 28, released September 2015; revised May 2016). https://ndb.nal.usda.gov/. Accessed 2 May 2016.

30. Pan L, Li R, Park S, Galuska DA, Sherry B, Freedman DS. A longitudinal analysis of sugar-sweetened beverage intake in infancy and obesity at 6 years. Pediatrics. 2014;134:S29-35.

31. USDA Agricultural Research Service. What We Eat in America Food Categories. www.ars.usda.gov/nea/bhnrc/fsrg (Accessed 5 July 2016).

\section{Submit your next manuscript to BioMed Central and we will help you at every step:}

- We accept pre-submission inquiries

- Our selector tool helps you to find the most relevant journal

- We provide round the clock customer support

- Convenient online submission

- Thorough peer review

- Inclusion in PubMed and all major indexing services

- Maximum visibility for your research

Submit your manuscript at www.biomedcentral.com/submit 